Антонюк І.Ю., к. т. н., доц.

Київський національний торговельно-економічний університет

м. Київ, Україна Google Scholar https://scholar.google.com.ua/citations?user=8XRMobAAAAAJ\&hl=r

\title{
ТЕХНОЛОГІЯ ЯГІДНОГО ДЕСЕРТУ 3 ПІДВИЩЕНИМ ВМІСТОМ ЙОДУ ТА СЕЛЕНУ
}

Дослідження останніх років показали, що структура харчування змінилась, внаслідок чого в щоденному харчовому раціоні населення України існує дефіцит макро- i мікроелементів: кальцію, калію, фосфору, магнію, йоду, селену, а також білків та ПНЖК [1].

Особливого значення набувають сьогодні питання створення нових композиційних продуктів, зокрема десертів, яких розроблено досить широкий асортимент. Однак пріоритетними будуть технології страв, які передбачають підвищення їх харчової цінності, збагачення складу біологічно активними компонентами, покращення органолептичних показників. На сьогодні одним із перспективних напрямів оптимізації асортименту продуктів спеціального призначення $\epsilon$ внесення харчових мікроінгредієнтів із метою підвищення їх біологічної цінності [2].

Мета досліджень - обгрунтування та розроблення технології ягідного десерту 3 порошком морської водорості цистозіри та дослідження його якості.

Матеріал і методи. Об'єкт досліджень - технологія ягідного десерту з використанням цистозіри. Предмет досліджень - цистозіра (ТУ У 21663408.001-2006), десерт із чорниці.

Вміст мінеральних речовин визначено атомно-абсорбційним методом на спектрофотометрі Techtron-AA-4 (Австрія). Вміст йоду також визначено методом інверсійної вольтамперометрії (прилад ABA-3, Росія) [3]. Повторюваність дослідів - п’ятикратна.

Чорниця - унікальна за своїм складом ягода, яка містить величезну кількість різних вітамінів і мікроелементів, що необхідні для правильної роботи нашого організму. До складу ягід чорниці входять цукри (до 6\%), лимонна, яблучна, молочна, бурштинова, щавлева, хінна кислоти $(1-1,2 \%)$, глюкозид гліконін, барвник 
міртилін, дубильні та пектинові речовини, мінеральні солі, вітаміни $\mathrm{A}, \mathrm{C}, \mathrm{B}_{1}, \mathrm{~B}_{2}, \mathrm{PP}$, макро- та мікроелементи (залізо, манган, селен, кобальт, мідь, золото, срібло, цинк) [4].

Технологія ягідного десерту складається із наступних основних стадій: свіжу чорницю миють та збивають у міксері 3 кефіром до отримання пюреподібної маси, додають цукрову пудру та ретельно перемішують, потім додають цистозіру (0,7\% на 100 г десерту) і знову перемішують (це сприяє рівномірному розподіленню добавки у готових стравах); білок яєць збивають у міцну піну і додають у чорничну масу; підготовлену масу викладають у неглибоку форму і охолоджують у морозильній камері до кремоподібної консистенції (в процесі охолодження кожні півгодини масу перемішують виделкою).

Під час подавання за допомогою кондитерського мішка наповнюють готовим десертом тонкі високі бокали, прикрашають гілочкою м'яти.

Завдяки використанню цистозіри в технології ягідного десерту підвищується вміст у ньому макро- та мікроелементів, особливо йоду та селену. Так, вміст йоду зростає у 9.4 рази і становить 150 мкг на 150 г десерту (вихід стандартної порції), що сприяє задоволенню добової потреби на 100\%. Вміст селену зростає з 1 мкг до 65 мкг на порцію, що задовольняє добову потребу у цьому мікроелементі на 93\%. На розроблений десерт отримано Патент України на корисну модель № 119733 - Спосіб виробництва десерту «Прованс» із використанням цистозіри.

На основі вищезазначеного та проведених досліджень, аналізу їх результатів можна зробити висновок, що виготовлений десерт характеризується не тільки як сучасний із відмінним смаком, а також корисний, що дозволяє споживати його 3 метою покращення як загального стану організму, так й забезпечення мінеральними речовинами раціону харчування. Розроблений десерт із покращеним нутрієнтним складом можна рекомендувати всім віковим групам (за винятком немовлят) населення України в межах фізіологічних норм замість їх традиційних аналогів.

\section{Список бібліографічних посилань}

1. Причины изменений в структуре питания современного человека. URL : http://opportunity.com.ua/teoriya/prichiny-izmenenij-v-strukturepitaniya-sovremennogo-cheloveka.html. 
2. Корзун В.Н. Теоретичні основи створення та вживання продуктів спеціального призначення / В.Н. Корзун // ж. Довкілля та здоров'я, 2009, № 1(48). - С. 63-68.

3. Tomcik P. Voltammetric determination of iodide by use of an investigated microelectrode array / P. Tomcik, D. Bustin // Fresenius J. Anal. Chem. - 2001. - Vol. 371. - P. 362-364.

4. Калорийность Черника. Химический состав и пищевая ценность. URL : https://health-diet.ru/base_of_food/sostav/433.php 